3 Ofner S, Baker RS. Visual loss in cryptococcal meningitis. $\mathcal{f}$ Clin Neuro Ophthalmol 1987; 7: 45-8.

4 Imperia PS, Lazarus HM, Lass JL. Ocular complications of systemic chemotherapy. Surv Ophthalmol 1989; 34: 209230.

5 Schatz NJ, Lichtenstein S, Corbett JJ. Delayed radiation necrosis of the optic nerves and chiasm. In: Glaser JS, Smith JL, eds. Neuro-ophthalmology. Symposium of the University of Miami and the Boscom Palmer Eye Institute, St Louis: of Miami and the Boscom

6 Pilay N, Gilbert JJ, Ebers GC, Brown JJ. Internuclear ophthalmoplegia and optic neuritis. Paraneoplastic ophthalmoplegia and optic neuritis. Paraneoplastic

7 Sebag M, Michaud J. Paraneoplastic optic neuritis and encephalomyelitis. Arch Neurol 1988; 45: 353-6.

8 Lester EP, Ultman JE. Lymphoma. In: Williams WJ, Beutlar E, Erslev AJ, Lichtman MA, eds. Hematology. New York: McGraw Hill, 1990: 1067-89.

9 Mackintosh FR, Colby TV, Podolsky WJ, Burke JS, Hoppe RT, Rosenfelt FP, et al. Central nervous system involvement in non-Hodgkin's lymphoma. An analysis of 105 cases. Cancer 1982; 49: 586-95.

10 Kansu T, Orr LS, Savino PJ, Schatz NJ, Corbett JJ. Optic neuropathy as initial manifestation of lymphoreticular diseases: a report a five cases. In: Smith JL, ed. Neuroophthalmology focus. 1980; $125-36$. 11 Kay MC. Optic neuropathy secondary to lymphoma. $\mathcal{F}$ Clin

12 Lanska DJ, Lanska MJ, Tomsak RL. Unilateral optic neuropathy in non-Hodgkin's lymphoma. Neurology 1987; 37: 1563-4.

13 Holte H, Saeter G, Dahl IMS, Abrahamsen AF. Progressive loss of vision in patients with high grade non-Hodgkin's lymphoma. Cancer 1987; 60: 2521-3.

14 Pasquier F, Leys D, Dubois F, Fallas P, Lessoin F, Petit H. Chiasm and optic nerve necrosis following radiation therapy. Neuro-Ophthalmology 1989; 9: 331-6.

15 Martins AN, Johnston JS, Henry JM, Stoffel TJ, Di Chiro G. Delayed radionecrosis of the brain. $\mathcal{F}$ Neurosurg 1977; 47: 336-45.

16 Kline LB, Kim JY, Ceballus R. Radiation optic neuropathy. Ophthalmology 1985; 92: 1118-23.

17 Zimmerman CF, Schatz NJ, Glaser JS. Magnetic resonance imaging of radiation optic neuropathy. Am $\mathcal{F}$ Ophthalmol 1990; 110: 389-94.

18 Henson RA, Urich HI. Cancer and the nervous system. Oxford: Blackwell, 1982: 522-3.

19 Sanderson PA, Kwabara T, Cogan DC. Optic neuropathy presumably caused by vincristine. Am $\mathcal{F}$ Ophthalmol 1978; 81: 146-50.

20 Shurin SB, Rekate KL, Annable W. Optic atrophy induced by vincristine. Paediatrics 1982; 70: 288-91.

21 Sandler SG, Tobin W, Henderson ES. Vincristine induced neuropathy. Neurology 1969; 19: 367-74.

\title{
Necrotic orbital melanoma arising de novo
}

\author{
Jerry A Shields, Carol L Shields, Ralph C Eagle Jr, Patrick De Potter, Glen L Oliver
}

\begin{abstract}
A 76-year-old man with compressive optic neuropathy secondary to a retrobulbar mass was managed by orbitotomy and removal of the mass. The lesion proved histopathologically to be an unusual orbital melanoma with massive central necrosis. There was no histopathological evidence of congenital melanocytosis. Dermatological and systemic evaluation before and after orbital surgery revealed no evidence of primary melanoma elsewhere. The patient developed hepatic metastasis 2 years after excision of the orbital tumour. It appears that the melanoma was a primary orbital tumour and not a metastatic melanoma from an occult primary lesion.

(Br f Ophthalmol 1993; 77: 187-189)
\end{abstract}

Wills Eye Hospital, Thomas Jefferson University, Philadelphia

Ocular Oncology Service J Shields

C Shields

P De Potter

Department of Pathology R C Eagle

Lehigh Valley Hospital, Allentown, PA, USA $\mathrm{G} \mathrm{L}$ Oliver

Correspondence to:

Jerry A Shields, MD,

Director, Ocular Oncology Service, Wills Eye Hospital, 900 Walnut Street

Philadelphia, PA 19107, USA.

Accepted for publication

8 December 1992
Orbital malignant melanoma most often occurs from direct orbital extension of uveal, conjunctival, or eyelid melanoma. ${ }^{1-4}$ Less often, orbital melanoma can occur as a metastasis from a previously diagnosed non-ocular melanoma. Primary orbital melanoma tends to occur in patients with predisposing melanocytic lesions such as congenital orbital melanocytosis or cellular blue naevus. ${ }^{1-18}$ Primary orbital melanoma arising de novo without such preexisting conditions is exceedingly rare. We report an unusual case of orbital melanoma that apparently developed as a primary orbital lesion in a patient who had no clinical or histopathological evidence of congenital orbital melanocytosis or cellular blue naevus. The lesion presented as a circumscribed orbital mass with extensive central necrosis.

\section{Case report}

A 76-year-old white male, who had no previous ocular problems except for mild amblyopia of the left eye, developed blurred vision in the right eye associated with epibulbar redness. An orbital computed tomography (CT) detected a retrobulbar mass. The initial clinical diagnosis was orbital inflammatory pseudotumour. After a 14 day course of oral corticosteroids failed to relieve his symptoms, the patient was referred to the ocular oncology service on 10 December 1990 for further evaluation and management.

The patient had a history of medically controlled hypertension, three previous myocardial infarctions, a prostatectomy for benign prostatic hypertrophy, and an inguinal herniorrhaphy. Two histopathologically confirmed seborrhoeic keratoses had been recently excised from his right scapular area. There was no history of ocular or cutaneous melanoma.

Our evaluation revealed best corrected visual acuities of $6 / 12$ in the right eye and $6 / 21$ in the amblyopic left eye. Intraocular pressures were normal. There was mild oedema of the right upper and lower eyelids and no proptosis. Ocular motility and colour plates were normal. Fundus examination of the right eye showed an elevated, hyperaemic optic disc and several juxtapapillary flame shaped haemorrhages. The left eye was normal except for decreased visual acuity due to amblyopia.

B-scan ultrasonography showed a rounded retrobulbar mass with acoustic hollowness and good sound transmission. CT revealed a $1.5 \mathrm{~cm}$ round, well circumscribed, intraconal mass abutting the globe and the optic nerve superotemporally (Fig 1). 


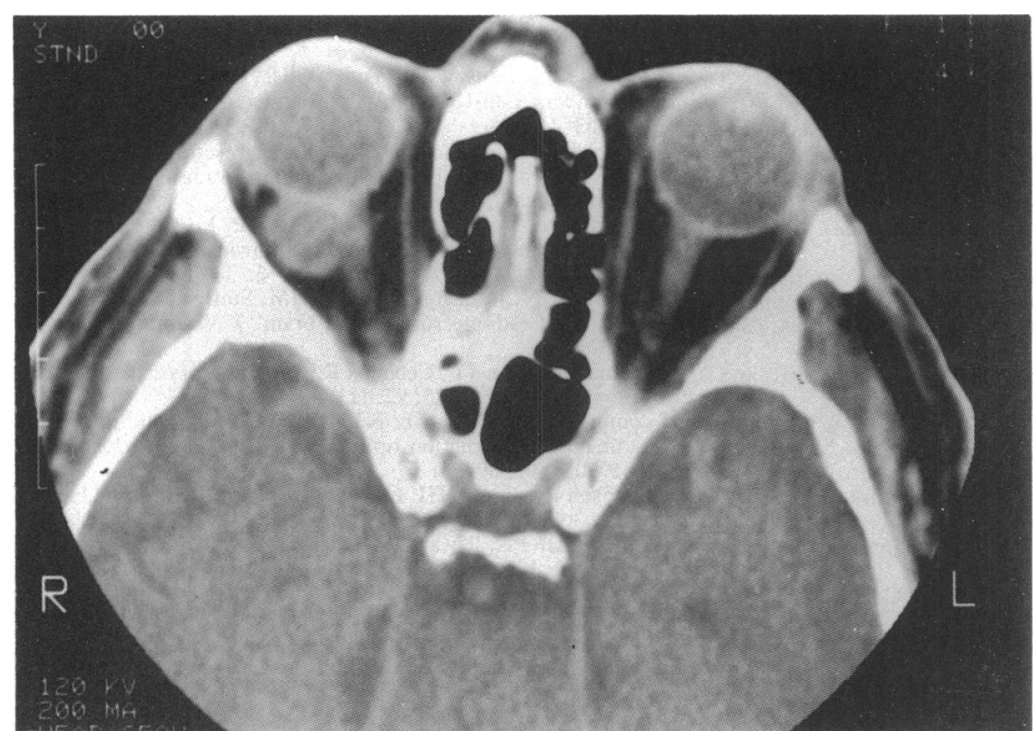

Figure 1 Orbital computed tomogram showing well circumscribed retrobulbar mass compressing the anterior portion of the optic nerve.

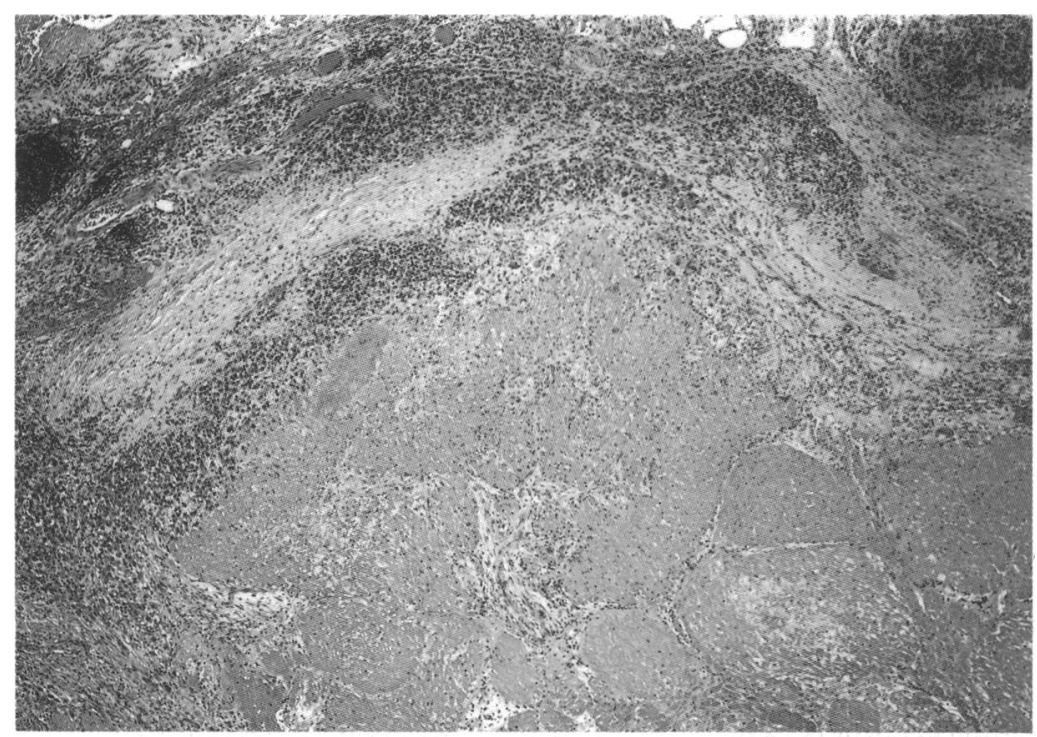

Figure 2 Low power photomicrograph showing rim or viable melanoma cells around a central area of necrotic tumour (haematoxylin and eosin $\times 15$ ).

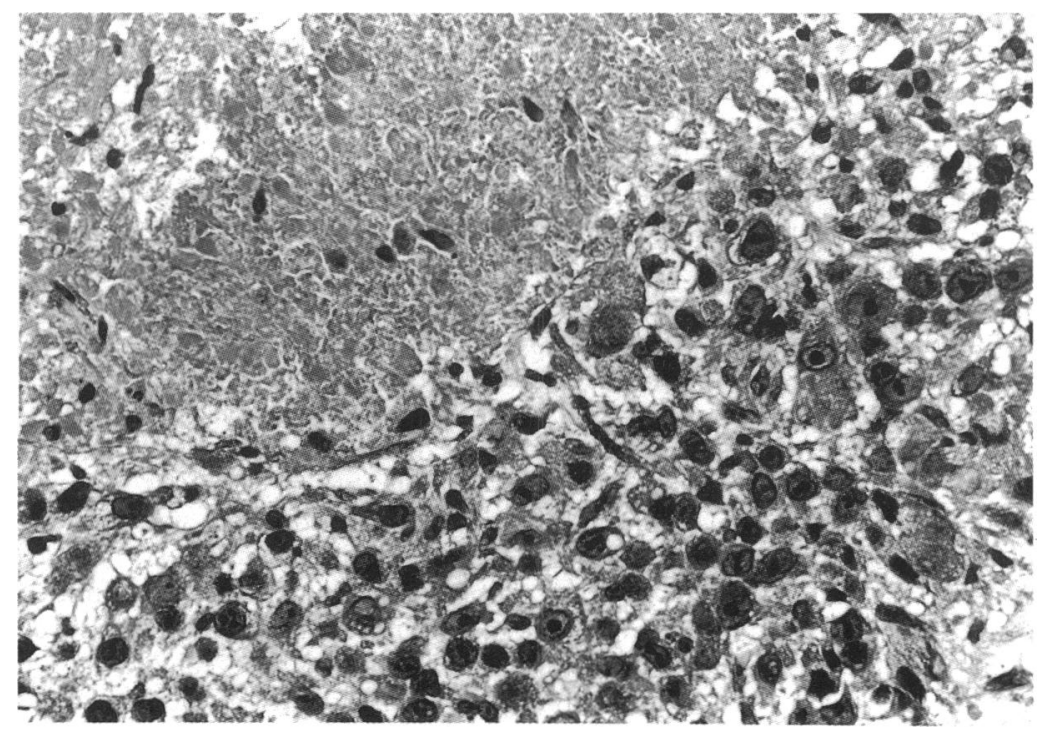

Figure 3 Photomicrograph of viable tumour cells near peripheral portion of lesion showing spindle and epithelioid melanoma cells (haematoxylin and eosin $\times 63$ ).
Since the lesion was causing optic nerve compression, pain, and visual impairment, it was elected to excise the mass via a superotemporal conjunctival approach with temporary disinsertion of the lateral rectus muscle. Local anaesthesia was employed because of the patient's advanced cardiovascular disease. At the time of surgery, the round mass was identified but was tightly adherent to the sclera and optic nerve. Intraoperatively, a capsular rent developed and a small amount of yellow cheesy material extruded from the lesion.

\section{Pathology and follow up}

Microscopic examination revealed an extensively necrotic tumour (Fig 2) composed of spindle and pleomorphic epithelioid cells some of which contained intracytoplasmic melanin (Fig 3). Sheets of necrotic tumour cells occupied the centre of the lesion. The necrotic zone was rimmed peripherally by viable tumour cells which were immunoreactive for melanoma specific antigen (HMB-45) and S-100 protein. No evidence of congenital melanocytosis, blue naevus, or cellular blue naevus was found. The final histopathological diagnosis was orbital malignant melanoma.

The patient subsequently underwent another thorough systemic evaluation, including chest $x$ ray, liver enzymes, dermatological evaluation, colonoscopy, and total body CT, all of which revealed no evidence of tumour. During the first few weeks after surgery, the patient's visual acuity in the right eye improved to $6 / 9$ and the optic disc oedema completely resolved. The patient developed liver metastasis and died about 22 months after excision of the tumour.

\section{Comment}

Although ophthalmologists occasionally encounter cases of secondary orbital extension of uveal melanoma, primary malignant melanoma of the orbit is exceedingly rare. In the Wills Eye Hospital series of 645 biopsied orbital tumours, there was only one primary orbital melanoma. ${ }^{19}$ The Mayo Clinic series of 674 orbital tumours included only three cases of primary orbital melanoma. ${ }^{20}$ Primary orbital melanoma usually occurs in patients who have predisposing pigmentary conditions such as congenital orbital melanocytosis, blue naevus, or cellular blue naevus. ${ }^{1}$ It has also developed in a patient who had received earlier orbital irradiation..$^{21}$

Perhaps the most puzzling aspect of the case reported here is whether the melanoma was a metastatic focus from an occult primary site or whether it was a primary orbital melanoma. Melanoma metastatic to the orbit almost always occurs in patients who have a known primary cutaneous melanoma, in whom it generally is a part of widespread melanomatosis. Affected patients are often in a near terminal state and their subsequent survival time is usually only a few weeks. The metastatic lesions usually contain epithelioid melanoma cells. Our patient had no history or findings of a primary melanoma and the necrotic portion of the tumour contained many spindle cells. Thus, we consider it unlikely 
that our patient had melanoma metastatic to the orbit. Although it is rare for a primary orbital melanoma to arise without pre-existing congenital orbital melanocytosis, we believe that the patient reported here does represent a rare example of a primary orbital melanoma arising de novo, without clinical or histopathological evidence of pre-existing orbital melanocytosis or blue naevus.

Extensive necrosis of the central portion of the tumour in our case caused the lesion to have a cystic appearance on CT. The yellow cheesy material encountered at surgery suggested the diagnosis of dermoid cyst. However, orbital dermoid cysts usually occur in children in a superotemporal anterior location and may be attached to bone. ${ }^{22}$ They can occasionally occur in the orbital soft tissues, in which cases they are usually located on the nasal side and are lined by conjunctival epithelium. ${ }^{22-24}$

Based on the clinical findings, histopathological features, and follow up information, we believe that the lesion in our patient represents a highly unusual primary orbital melanoma.

Presented at the 1991 Meeting of the Pan American Ophthalmic Pathology Society, Los Angeles, CA, 11 October 1991.

This work was supported by the Eye Tumor Research Foundation Inc, Philadelphia, PA, the Robert Beckman Endowment Fund, Philadelphia, PA, and the Macula Foundation, New York.

1 Shields JA. Primary melanocytic tumors. In: Shields JA, ed. Diagnosis and management of orbital tumors. Philadelphia: Diagnosis and management

2 Shields JA, Shields CL. Posterior uveal melanoma: clinical and pathologic features. In: Shields JA, Shields CL, eds. Intraocular tumors. A text and atlas. Philadelphia: Saunders, 1992: 117-36.

3 Jakobiec FA, Font RL. Orbit. In: Spencer WH, Font RL, Green WR, Howes EL, Jakobiec FA, Zimmerman LE, eds. Ophthalmic pathology. An atlas and textbook. Philadelphia: Saunders, 1986: 2656-60.
4 Shields JA. Orbital malignant melanomas. In: Hornblass A, ed. Ophthalmic plastic and reconstructive surgery. Baltimore: W. Ophthalmic plastic and reconstructive

5 Coppeto JR, Jaffe R, Gillies CG. Primary orbital melanoma. Arch Ophthalmol 1978; 96: 2255-8.

6 Drews RC. Primary malignant melanoma of the orbit in a negro. Arch Ophthalmol 1975; 93: 335-6.

7 Dutton JJ, Anderson RL, Schelper RL, Purcell JJ, Tse DT. Orbital malignant melanoma and oculodermal melanocytosis: report of two cases and review of the literature. Ophthalmology 1984; 91: 497-507.

8 Ellis D, Spencer WH, Stephenson CM. Congenital neurocutaneous melanosis with metastatic orbital malignant melanoma. Ophthalmology 1986; 93: 1639-42.

9 Foster J. An encapsulated orbital melanoma. Br $\mathcal{F}$ Ophthalmol 1944; $21: 293-8$.

10 Hagler WS, Brown CC. Malignant melanoma of the orbit arising in a nevus of Ota. Trans Am Acad Ophthalmol arising in a nevus of Ota.
Otolaryngol 1966; 78: 817-22.

11 Haim T, Meyer E, Kerner H, Zonis S. Oculodermal melanocytosis (nevus of Ota) and orbital malignant melanoma. Ann Ophthalmol 1982; 14: 1132-6

12 Henderson JW, Farrow GM. Malignant melanoma primary in the orbit. Report of a case. Trans Am Acad Ophthalmol Otolaryngol 1972; 76: 1487-90.

13 Jakobiec FA, Ellsworth RM, Tannenbaum M. Primary orbital melanoma. Am $\mathcal{f}$ Ophthalmol 1974; 78: 24-39.

14 Jay B. Malignant melanoma of the orbit in a case of oculodermal melanosis (nevus of Ota). Br $\mathcal{F}$ Ophthalmol 1965; 49: 359-63.

15 Rottino A, Kelly AS. Primary orbital melanoma. Case report with review of the literature. Arch Ophthalmol 1942;27:934 49.

16 Wilkes SR, Uthman EO, Thornton CN, Cole RE. Malignant melanoma of the orbit in a black patient with ocular melanocytosis. Arch Ophthalmol 1984; 102: 904-6.

17 Wolter JR, Bryson JM, Blackhurst RT. Primary orbital melanoma. Ear Nose Throat F 1966; 45: 64-7.

18 Rice CD, Brown HH. Primary orbital melanoma associated with orbital melanocytosis. Arch Ophthalmol 1990; 108: $1130-4$.

19 Shields JA, Bakewell B, Augsberger JJ, Flanagan JC. Classification and incidence of space-occupying lesions of the orbit. A survey of 645 biopsies. Arch Ophthalmol 1984; 102: 1606-11.

20 Henderson JW, Farrow GM. Orbital tumors. 2nd ed. New York: Decker, division of Thieme-Stratton, 1980: 325-43.

21 Leff SR, Henkind P. Rhabdomyosarcoma and late malignant melanoma of the orbit. Ophthalmology 1983; 90: 1258-60.

22 Shields JA. Cystic lesions of the orbit. In: Shields JA, ed. Diagnosis and management of orbital tumors. Philadelphia: Saunders 1989: 94-7.

23 Jakobiec FA, Bonanno PA, Sigelman J. Conjunctival adnexal cysts and dermoid. Arch Ophthalmol 1978; 96: 1404-9.

24 Shields JA, Augsburger JJ, Donoso LA. Orbital dermoid cys of conjunctival origin. Am f Ophthalmol 1986; 101: 726-9.

\title{
Late onset esotropia in monozygous twins
}

\author{
S Ahmed, J D H Young
}

\begin{abstract}
Monozygous twins who developed typical acute late onset esotropia are described. Neither had evidence of other neurological disease and both responded well to bimedial rectus muscle recessions. This twin presentation suggests a hereditary basis for the development of late onset esotropia in at least some cases. It provides further support for a policy of avoiding invasive CNS investigations in those patients who have binocular potential and are otherwise normal.

(Brf Ophthalmol 1993; 77: 189-191)
\end{abstract}

The sudden onset of strabismus in a previously normal child over the age of 4 is alarming to the parents. If there are no local aetiological factors it will also be of concern to the treating ophthalmologists aware that this might be the presenting sign of serious intracranial pathology. Typically strabismus secondary to neurological disease will be paralytic but concomitant strabismus is also a recognised presenting feature, especially of posterior fossa lesions. ${ }^{1}$

Concomitant esotropia not associated with any detectable neurological disorder may also occur in this age group. This has been described as late onset or normosensorial esotropia ${ }^{2}$ and is characterised by:

(1) An acute onset of esotropia with diplopia, in some cases initially intermittent for a short period.

(2) A potential for normal binocular function, demonstrable on orthoptic testing.

(3) No refractive error of relevance to the strabismus. 